\title{
Fraud and Forensic Accounting Education: Prospects and Challenges in Nigeria
}

\author{
Wilson E. Herbert ${ }^{1}$, Francis Onyilo ${ }^{2}$, Emeka E. Ene ${ }^{2} \&$ Ioraver N. Tsegba ${ }^{3}$ \\ ${ }^{1}$ Dept. of Banking \& Finance, Faculty of Management Sciences, Federal University, Otuoke, Nigeria \\ ${ }^{2}$ Dept. of Accounting \& Finance, Faculty of Management \& Social Sciences, Baze University, Abuja, Nigeria \\ ${ }^{3}$ Dept. of Accounting \& Finance, Federal University of Agriculture, Makurdi, Nigeria \\ Correspondence: Wilson E. Herbert, Dept. of Banking \& Finance, Faculty of Management Sciences, Federal \\ University, Otuoke, Nigeria. E-mail: weherbert12@gmail.com
}

Received: April 14, 2017

Accepted: May 27, 2017

Online Published: June 7, 2017

doi:10.5539/ijbm.v12n7p146

URL: https://doi.org/10.5539/ijbm.v12n7p146

"What the use of fingerprints was to the 19th century and DNA analysis to the 20th, forensic accounting will be to the 21st century". Gordon Brown, Chancellor of the Exchequer, 10 October 2006.

\begin{abstract}
This study first investigates the availability of fraud and forensic accounting (FFA) education in Nigeria. The paper then analyses the perceptions of academics and practitioners on the demand for, relevance and integration of, FFA in Nigeria. The data obtained through a questionnaire survey was analysed using descriptive statistics, Kruskal-Wallis (K-W) and Chi-Square tests. The results (i) indicate an increasing market demand for fraud examiners and forensic accountants; and (ii) suggest that FFA be given adequate coverage in the accounting curriculum in response to market demand. On the benefits of FFA education and training, there is virtual unanimity that it will: (i) widen the employment horizon and opportunities for graduates; (ii) help to combat fraud, corruption and financial crimes, (iii) strengthen the credibility of financial reporting, and (iv) help to rebuild investors' confidence and trust in financial reports. The findings also support integration at both the undergraduate and postgraduate levels. The policy implication draws attention to regulatory importance and expediency of integrating FFA education into the accounting curriculum. This calls for regulatory initiative in developing the Benchmark Minimum Academic Standards (BMAS) for FFA programmes at the undergraduate and postgraduate levels.
\end{abstract}

Keywords: fraud and forensic accounting education, fraud examination, forensic accounting, accounting curriculum, accounting profession, benchmark minimum academic standards, Nigeria

\section{Introduction}

The high profile financial scandals that rocked the world in the 1990s and the increasing reported cases of corruption, occupational fraud and money laundering not only eroded investor confidence and public trust in corporate financial reports, but also raised global consciousness on the need to tighten the reins on corporate governance. Apart from the eight banks of 2009 (Note 1), Nigeria has acquired a notoriety for '419' (Note 2), internet-related fraud and a range of economic and financial crimes. Those entrusted with public funds for provision of citizen welfare, security and public services and those assigned the responsibility of ensuring public oversight, transparency and accountability in governance, have all reportedly been implicated in state-wide 'palace' corruption, fraud and economic crimes. Even the judiciary presumed to be the 'last hope of the common man' is being increasingly compromised and implicated in the opportunistic benefits of corruption and fraud. Thus, for both nation states and the business community, there is a growing public demand for increased accountability, transparency and vigilance in corporate governance.

Since then, the trajectory of corporate governance has been in flux, not just in terms of new governance codes and regulations, but in "providing truly good governance - that is, governance that doesn't just prevent misdeeds but actually improves the corporation and figures out the "how" of adding value" (Charan, 2005). The contextual background to the heightened interest in FFA is traceable to corporate governance concern of at least three antecedent kinds. First, the corporate failures became scandalous not only because of the characteristics of the companies (size, age and their reported past successes) that collapsed and their multiplier effect on national and 
global economies, "but also because of the discovery that questionable accounting practice was far more insidious and widespread than previously envisioned" (Bhasin, 2013). Second, the plethora of incriminating evidence linking these egregious accounting practices to the corporate scandals and failures led to a number of national and global corporate governance initiatives (Herbert, Ene \& Tsegba, 2014). Prior to the fall of Arthur Andersen, accountants have historically had a determinative role in fostering investor confidence and public trust through audit reports. Many large audit firms, like Arthur Andersen, had embarked on an income trajectory that placed premium on hefty audit fees over trust and accountability, and quality and honest accounting. The implication of Arthur Andersen's opprobrious accounting practices on the accounting profession is succinctly captured by Alexander, Burns, Manor, McRoberts \& Torriero in Chicago Tribune of September 1, 2002 under the caption "The fall of Andersen". They noted that "The quiet dilution of standards and the rise of auditor-salesmen at Andersen are central to the scandals that have cost investors billions of dollars, eliminated thousands of jobs and threatened the retirement security of millions of citizens. Most of all, they have cast suspicion over the financial reports that Americans rely on to judge the health of companies where they work and invest." Hitherto, the accounting profession was largely self-regulated. But, the series of fiascos suffered since the late 1990s (a) weakened its self-regulatory status; (b) questioned the capacity of the profession to self-correct or purge itself from the opportunistic practices of its members, especially the leading large accounting firms, and (c) led to national and international calls for changes in financial reporting standards.

Third, and in consequence, the corporate failures triggered the U.S. congressional action that resulted in the Sarbanes-Oxley Act of 2002 and review of auditing standards (Statement on Auditing Standard No. 99) that require companies and their auditors to be more proactive in detecting and preventing fraud. In effect, the events raised the consciousness of regulators and policy makers to the negligence or weakness of extant corporate governance practices across the board. The upshot was that the architecture of the accounting profession had to be redrawn in at least four ways. First, a greater emphasis has been placed on integrity of the financial reporting system. Second, the global concern for a uniform financial reporting framework resulted in the international harmonization of financial reporting standards, called the International Financial Reporting Standards (IFRS). Thus, the transition to this new globalized financial reporting system is an eloquent endorsement of the international consensus on IFRS as a benchmark for gauging the comparative financial health of economic entities across the world (Herbert, Ene, \& Tsegba, 2014). Third, and important for this study, the configuration of the accounting profession had to pay greater attention to prevention and detection of financial statement fraud and related vices. Finally, the global interest in new corporate governance measures goes beyond merely widening the ambit of corporate responsibility of the accounting profession in certifying financial reporting integrity to encompass proactive measures to detect and prevent fraud, corruption and financial crimes.

Fraud and forensic accounting (FFA), as a field of study, continues to gain momentum especially in developing countries where systemic corruption, fraud, bad leadership and governance, and economic mismanagement have unleashed untold hardship on their economies, poverty and poor social and physical infrastructure. The establishment of FFA as an academic discipline is a recognition of the fundamental benefits of a systematic corporate governance architecture, incorporating education and training, to equip fraud examiners and forensic accountants with the requisite skill-set to confront the opportunistic distortions and systemic corruption bedevilling socioeconomic and political development, especially in Sub-Saharan Africa (SSA) with weak legal institutions (Efiong, 2012; Zango, 2012).

Presently, there is no tertiary education institution in Nigeria offering FFA as an academic programme either at the undergraduate or postgraduate level. What is at best available, and in only a handful of tertiary institutions, is a three-credit unit course or a module subsumed under an auditing course. Thus, most Nigerian certified fraud examiners (CFE) and forensic accountants obtained their professional qualifications from, and are practising under the professional license of, foreign established professional associations, such as the Association of Certified Fraud Examiners (ACFE), USA, and the Institute of Certified Forensic Accountants (ICFA). The nonexistence of systematic formal education in FFA is a serious policy and regulatory inattention by the Federal Ministry of Education and the tertiary education regulatory bodies under its supervision. A formal education and training platform should provide the blend of complementary base of knowledge, skills and attitudes required for fraud examiners and forensic accountants. The observation of Rezaee, Crumbley \& Elmore (2004) in the USA is apt that: "there is little background data available (in Nigeria), and rare evidence of post-Enron, Andersen, and other financial scandals, with respect to the integration of of forensic accounting (and fraud examination) education into the accounting curricula and particularly whether academics' actions are consistent with the needs of practitioners for well-trained and knowledgeable forensic accountants (and fraud examiners)". 


\subsection{Objectives of the Study}

The foregoing is the motivation behind the present survey. Broadly, this study seeks to assess the perceptions and perspectives of Nigerian academics and practitioners in FFA. Specifically, the objectives are to assess: (i) the demand for, and interest in, FFA education; (ii) the beneficial effects of FFA education, and (iii) the integration process of FFA education into academic curriculum at the tertiary level. A detailed theoretical review of FFA has been undertaken by Herbert, Tsegba, Ene \& Onyilo (2017), as part of a larger study. The focus of the present paper is on empirical assessment of FFA education. Unlike the Rezaee et al.'s study whose focus was on forensic accounting education, the present study amplifies the interest to include fraud examination. The rationale for this dyadic analysis is founded on the following precepts. First, as Herbert et al. (ibid.) observe, fraud examination and forensic accounting are conceptually different but related. Both are evolving concepts and have become a fast developing specialist field of accounting. Second, the analytical prescience of what fraud examiners and forensic accountants do is anchored on the fundamental question of why people commit fraud or financial crime. For example, knowing that a mammal cannot survive without oxygen (breathing) easily explains why asphyxiation leads to death.

Fraud theories (chiefly, fraud triangle and fraud diamond) provide some understanding of the trajectory of FFA, in terms of who, what, when, where, how, and why, of fraud. The theoretical foundation underlying the phenomenon of fraud is conterminous with the explanatory powers of forensic accounting. Most forensic accounting surveys are essentially fraud surveys (Rezaee, Crumbley \& Elmore, 2004; Rezaee \& Burton, 1997; Peterson \& Keiber, 1999; KPMG, 2003; PWC, 2003; Ramadhan, 2015). Although FFA is much older than commonly thought (Crumbley, 2001), it is still a "new growth area in accounting" (Crumbley \& Apostolou, 2002). However, FFA education and training have over the years progressed from being a function of the continuing professional development programmes of professional accounting bodies (Ramadhan, 2015), to its current state where it is being offered as a credit course in many universities (Rezaee \& Burton, 1997; Peterson \& Keiber, 1999; Rezaee, Reinstein \& Lander, 1996; Peterson \& Reider, 2001). To be sure, FFA education, training and research are still at the embryonic stage, especially in Africa, with no consensus yet on their dimensions.

The rest of the paper is organised as follows. To strengthen the association to subsequent analysis of participant groups' (academics' and practitioners') responses to the questionnaire, the relevant trends of extant academic FFA education are summarised in the next section, Section 2. Section 3 describes the methodology including details on the data gathered from responses to questionnaire on perceptions of academics and practitioners. Section 4 presents the results and general observations, and Section 5 concludes the paper.

\section{Review of Prior Studies}

The purpose of this section is not to present a historical evolution of FFA education and research but to focus on the usefulness of some pertinent FFA research to critical thinking and integration into the accounting curriculum. A number of studies have given insights into a broad range of issues related to FFA education. For instance, Rezaee and Burton (1997) tried to discern the views of academics and certified fraud examiner-practitioners about the existing and future direction and the role of forensic accounting education. They concluded, inter alia, that forensic accounting education and practice would witness a steady increase in demand and called for its integration into the accounting curriculum either as a separate course or as modules in accounting and auditing. Carnes and Gierlansinki (2001) examined the mismatch between the supply of, and demand for, auditors with forensic accounting skills, and noted that universities have been slow in their supply response, particularly, in designing courses that would improve students' understanding of fraud or their abilities to detect fraud.

Rezaee et al. (2004) surveyed the opinions of academics and practitioners about the importance, relevance and delivery of forensic accounting education. They came to the same conclusion that the demand for, and interest in, forensic accounting would continue to increase as more universities planned to provide forensic accounting education, against the backdrop of its perceived benefits to the accounting profession and the global economy. While advocating for more innovative pedagogic methods and a more integral approach to forensic accounting education, they suggest that, in the interim, its structure, content and delivery should be incorporated into extant accounting programmes.

The authors further assert that FFA education has not received adequate coverage in the accounting curriculum vis-à-vis labour market needs. Additionally, they aver that forensic accounting courses have emerged in the same fashion as international accounting courses in the 1980s and e-commerce courses in the 1990s, with individual faculty and accounting programmes designing courses based on their interests, skills, philosophies, and demands. They then suggest that accounting programmes should continuously assess the structure, content, and delivery of 
forensic accounting education, and explore innovative teaching methods and a more integral approach to its coverage. The inference is that this would assist graduating accounting students to successfully pursue FFA careers and ease their transition from the classroom to professional career in a seamless symbiotic relationship between town and gown.

Okunbor and Obaretin (2010) examined the efficacy of the application of forensic accounting services in curbing fraudulent activities in corporate organizations in Nigeria. Their evidence suggests that forensic accounting services can deter fraudulent dispositions. Efiong (2012) surveyed the level of awareness of forensic accounting by accounting students in a number of Nigerian universities. They found a very low level of awareness among students. They concluded that the integration of forensic accounting into the universities' accounting curriculum would have a huge potential in enhancing students' skills and competencies and could serve as a veritable resource for mitigating fraud in Nigeria. Zachariah, Masoyi, Ernest and Gabriel (2014) studied the application of forensic auditing in controlling fraud in Nigerian banks as a corrective measure to the rising rate of bank frauds, given the failure of audits to detect them. They suggest employment of forensic auditing in Nigerian banks by amending extant statutes, to make forensic auditors an essential part of the statutory audit framework. Contemporaneously, the increasing regulatory pressure on auditors to expand the repertoire of auditing to include detection of fraudulent financial statements has helped to reinforce the demand for FFA education and training.

It might be argued that accounting curricula should be driven by the academics' ideas and visions of what is in the best interest of students, and not by practitioners' demands. However, global best practices dictate the importance of aligning accounting curricula (or any field of learning, for that matter) with the needs of the labour market if the accounting (or such academic) programmes are to survive or thrive. After all, institutions of higher learning, apart from being employers of labour themselves, are the laboratories and training grounds for breeding and grooming students (their products) for the needs of the larger labour market. This academic-practitioner synergy in teaching and learning helps to allay employers' concerns about accounting and finance programmes being out of touch with reality (See, Herbert \& Wallace, 1996; Rezaee et al., 2004).

\subsection{Specification of Hypotheses}

Three hypotheses are formulated to both address the central issues about, and secure the respondents' harmony on perceptions on, key issues regarding FFA education and training in Nigeria. Lack of consensus among the key stakeholders (academics and practitioners) could impede policy efforts in establishing a systematic basis of FFA education and training. Accordingly, these hypotheses, formulated in the null form, also serve as robustness checks on respondents' perceptions on FFA education and training.

$\mathrm{H}_{01}$ : There are no significant differences between the perceptions of academics and practitioners on the demand for, and interest in, FFA education.

$\mathrm{H}_{02}$ : There are no significant differences between the perceptions of academics and practitioners on the benefits of FFA education.

$\mathrm{H}_{03}$ : There are no significant differences between the perceptions of academics and practitioners on the integration process of FFA education and training.

\section{Methodology}

As an exploratory study, a set of questionnaires was designed to elicit opinions from academics and practitioners in Nigeria about the demand, relevance and delivery of FFA education in Nigeria. The practitioners were drawn from government agencies, banks, big law firms, and the big-4 accounting firms. The academics were from Nigerian universities and Polytechnics. The sample respondents were chosen based on their experience, exposure and familiarity with both the education and practice of fraud examination and forensic accounting. Most of them are forensic accountants, fraud examiners and, in the case of lawyers, have been involved in fraud and financial crimes cases as either prosecution or defence attorneys. So, their familiarity with the phenomenon of interest equips them with the requisite knowledge to express usable and decisive opinions on the topical issue.

The population of professional accountant-respondents was developed from the membership registers of Association of National Accountants of Nigeria (ANAN) and the Institute of Chartered Accountants of Nigeria (ICAN) - the two statutory professional accountancy bodies in Nigeria - the Nigerian Chapters of the Association of Certified Fraud Examiners (ACFE), and the Institute of Certified Professional Forensic Accountants (ICPFA). The population of lawyer-respondents was developed with the help of members of the Nigerian Bar Association (NBA). The population of academic respondents was developed through personal knowledge and links with the universities and polytechnics offering forensic accounting course as part of their accounting curriculum. Eliciting the views of knowledgeable groups helps to provide useful insights into the 
education and training needs of practitioners from providers and users in the field. Academics were chosen because they are involved in developing the curricula of accounting, auditing and forensic accounting. This research addressed relevant academic issues and, as such, the educational respondent group played an important role in developing our results. The range of respondents' perspectives may offer important insights into the current coverage and future direction of FFA education, training and practice.

\subsection{Sample and Instrumentation}

The study adopted the purposive (Note 3) and multi-stage sampling (Note 4) techniques. In the first stage of sampling, a sample of three (3) states was purposively selected from the thirty-six (36) states in Nigeria. This selection was based on the availability of fraud cases and practitioners who had been involved in their prosecution or defence. In the second stage, we sampled the Nigerian Universities and Polytechnics in the three states and selected six (6) universities and polytechnics from whom the accounting academic-respondents were sampled. These institutions were chosen because they have forensic accounting course in their accounting programme. Next, we sampled practitioners in the three states, with five (5) practitioner-groups drawn from ten (10) organizations. In carrying out purposive and multi-stage sampling, it is important to be conscious of at least three factors which can influence sample representativeness: sampling procedure, sample size, and respondents' participation (response). Obtaining a representative sample, sample size and achieving usable response rate in research involving idiosyncratic populations, where task-specificity and knowledge is scarce and idiosyncratic (Note 5), or where data is hard to come by, are important methodological challenges. These considerations were factored into the sampling techniques.

The instrument used to elicit opinions from the Nigerian academics and practitioners is a slightly modified version of an instrument used by Rezaee et al. (2004) for the U.S. survey. As proposed by Herbert \& Wallace (1996), replication studies tend to inherit the limitations of the original study. The U.S. study derives the questionnaire items from U.S. literature (textbooks and academic articles). As canvassed by Herbert \& Wallace (1996), there are reasons for replicating the U.S. study in Nigeria. Essentially, FFA is a new and specialised area of knowledge whose education has not been well-developed or documented, especially in developing countries. Second and very important, there is as yet no Benchmark Minimum Academic Standard (BMAS) developed for the course in the Nigerian University System (NUS). This means that fraud examination and forensic accounting is not offered as a full-fledged undergraduate or postgraduate degree programme in Nigerian universities. Third and equally important, there is no indigenous statutory professional body with specialisation in forensic accounting and/or fraud examination. At best, the two accountancy bodies (ANAN and ICAN) established centres for forensic accounting education, as a platform for creating awareness of the growing importance of this newly specialised field for their members.

Presently, there are local chapters of the North American bodies, such as the ACFE and ICPFA. Above all, developed countries, especially the U.S. and Europe, have always blazed a trail in all spheres of human endeavour and knowledge, and forensic accounting is no exception. Developing countries naturally follow in their footsteps, mutatis mutandis. Extant certificated forensic accountants and fraud examiners in Nigeria are members of these foreign bodies. For these reasons, adopting the survey instruments developed for U.S. academics and practitioners commonly yields research economies in adaptability and replication respects. Following Herbert \& Wallace (1996), different contexts of research in FFA help to define the status of education and practice in FFA; they help to identify global FFA topics of interest and support globalization of FFA curricula and practice. They also help to build a literature on comparative national studies on FFA, which is presently sparse although there is a growing literature on comparative national studies in other areas such as on accounting, finance, marketing, and management.

However, the present study differs from the U.S. study (Rezaee et al., 2004) in some respects. First, it differs in terms of data collection. The respondents to our survey were drawn from accounting academics and practitioners. Second, the study sample is based on Nigerian academics and practitioners drawn from both public and private sectors, to wit, government agencies, banks, law firms, the big-4 accountancy firms, and universities. However, notwithstanding the differences in the study samples and data collection, significant differences between the views of Nigerian and U.S. accounting academics and practitioners are not expected because academics and practitioners in the same or similar discipline or profession are likely to embrace attitudes and behaviours common to their counterparts in other countries, especially if there are no significant language and cultural differences in the professional practice. Above all, Herbert \& Tsegba (2013) posit that it is now an article of faith that IFRS has not only become a common global accounting and financial language, but also is completely reshaping the architecture of financial reporting. The four main sections of the questionnaire asked respondents for their perceptions on the: (1) future demand for and interest in FFA; (2) current and future methods of delivery 
of FFA education; (3) benefits, support, and obstacles of FFA coverage; and (4) degree of relative importance of topics related to FFA education. The last section was about demographic and background information for classification purposes.

Further, the shorter three-page questionnaire administered to a wide variety of fraud and forensic professionals about (1) the future demand and interest in forensic accounting; (2) the importance and benefits of forensic accounting education and practice; (3) the relative importance of forensic accounting topics; (4) how forensic accounting might be integrated into the accounting curriculum; and (5) the level at which it should be offered. The last section requested for the respondents' general comments on forensic accounting education and practice. The respondents' opinions and perceptions were rated using a Likert-type scale questions. Participants were asked to rate on a five-point scale the level of agreement on, and the importance or severity level of, a range of factors. The scales were anchored at each end with the descriptors "strongly disagree" to "strongly agree", "least important," to "most important," and "not severe," to "very severe.". The rating scales were coded on a weight of 1 for 'strongly disagree', 'least important' or 'not severe' to 5 for 'strongly agree', 'most important' or 'very severe', as the case may be.

After pre-testing, the questionnaire was administered to 195 respondents as follows (Table 1): 141 practitioners and 54 accounting lecturers. The practitioners were drawn from government agencies, banks, law firms, and the big-4 accountancy firms. In total, 111 and 37 useable responses were returned by practitioners and academics, respectively. This represents approximately, a response rate of $79 \%$ for practitioners and $69 \%$ for academics. The overall response rate of $76 \%$ is quite high relative to most survey studies.

Table 1. Summary of questionnaire administration by organization

\begin{tabular}{lccc}
\hline Respondents' Group & No. Administered & No. Returned & Response Rate (\%) \\
\hline Government agencies & 15 & 11 & 73.3 \\
Banks & 18 & 75 & 93.7 \\
Attorneys & 30 & 15 & 50.0 \\
Big-4 accountancy firms & 16 & 10 & 62.5 \\
Universities & 54 & 37 & 68.5 \\
\hline Total & 195 & 148 & 75.9 \\
\hline
\end{tabular}

Although this usable response rate is better than Rezaee et al.'s, the disparity between the sample sizes of academics and practitioners on the one hand and the presence of non-responses in both sample groups on the other, raise an interpretational problem. Where non-responses or low responses occur in survey questionnaires, it may be due to (a) the belief by such non-respondents that the topical research does not align or cannot help with their research needs or interests; (b) the non-respondents have no clue about the subject matter and therefore exhibit nonchalance by not responding, or (c) unwillingness of the non-respondents due to bounded rationality (Note 6). In order to gauge the bias due to non-response, the following evaluations were made, as advocated by Herbert \& Wallace (1996): (1) a comparison of late respondents with early respondents, as recommended by Oppenheim (1966), Armstrong \& Overton (1977), Wallace \& Mellor (1988); a comparison of the first and second mailings (Wallace \& Mellor, 1988; Herbert \& Wallace, 1996); and (3) a comparison of demographic profile of respondents and non-respondents. Where a survey entails two or more mailings, and generates non-usable responses (as is often the case in many postal or mail surveys), or where a survey involves respondents with different demographic profiles (as is often with perception surveys), it is possible, as was done in this study, to evaluate the discrepancy between a set of observed frequencies and expected frequencies of returns among (i) the first, second, etc. mailings or questionnaire returns, (ii) usable and non-usable questionnaire returns, and/or (iii) demographic profile of usable respondents.

\section{Data Analyses}

The study hypotheses were tested using frequency analyses, descriptive statistics, Kruskal-Wallis (K-W) and Chi-Square tests. The K-W test is a nonparametric analysis of variance test used to determine if there are statistically significant differences between two or more samples of an independent variable. It tests the null hypothesis that the populations from which the samples are drawn have identical distribution functions against the alternative hypothesis of differences. While the Chi-Square (test of independence) tests if the two categorical variables in the population are independent, the K-W test examines differences in responses in the ranked data. The K-W test was also performed to investigate demographic differences in the responses. 


\subsection{Respondent Characteristics}

In about $50 \%$ of the cases, the practitioner-respondents were bankers, followed by financial accountants (27\%), and lawyers (13.5\%) (Table 2). For the academic-respondents, over 60 percent were from the Senior Lecturer cadre and above. This respondent profile reinforces stakeholder-knowledge and familiarity which is a dynamic of the academic-practitioner synergy that supports the FFA integration prospects.

Table 2. Demographic profile of sample

\begin{tabular}{lcc}
\multicolumn{2}{l}{ Table 2a: Demographic Profile by Practitioner Type } & Percent \\
\cline { 2 - 3 } Profession & Frequency & 27.0 \\
\hline Financial accountant & 30 & 9.0 \\
Forensic accountant & 10 & 49.6 \\
Banker & 55 & 0.9 \\
Auditor & 1 & 13.5 \\
Lawyer & 15 & 100.0 \\
Total & 111 & \\
\hline & & Percent \\
\hline Table 2b: Demographic Profile of Academics by Rank & 32.5 \\
\hline Rank & Frequency \\
\hline Professor/assoc. professor & 12 & 29.7 \\
Senior lecturer & 11 & 10.8 \\
Lecturer & 4 & 27.0 \\
Assistant lecturer & 10 & 100.0 \\
Total & 37 & \\
\hline
\end{tabular}

\section{2 Results}

These are considered, seriatim, with respect to the study objectives and hypotheses.

\subsubsection{Demand for Fraud and Forensic Accountants (FFA)}

The first objective of this study is to ascertain the demand for FFA. To achieve this, respondents were asked their perceptions on the demand for and interest in, and benefits of, FFA education and practice in Nigeria. Table 3 presents their responses with an overall increase in demand for, and interest in, FFA, in this order: fraud examination (83.6\%), litigation support (71.0\%), and expert writing $(60.0 \%)$.

Table 3. Aggregate demand for forensic accountants: academics and practitioners

\begin{tabular}{lccc}
\hline & Litigation Support & Expert Witnessing & Fraud Examination \\
\hline Increase? & $71.0 \%$ & $60.0 \%$ & $83.6 \%$ \\
Remain the same? & $6.5 \%$ & $27.9 \%$ & $4.4 \%$ \\
Decrease? & $12.4 \%$ & $7.4 \%$ & $5.9 \%$ \\
Total respondents \% & $89.9 \%$ & $95.3 \%$ & $93.9 \%$ \\
\hline
\end{tabular}

Assessing the respondents' opinions separately, the expectations of academics are found to be much higher than those of practitioners in the three areas (Table 4). On the demand for litigation support, $84 \%$ of academics expect a future increase as against $75 \%$ of practitioners. On expert witnessing, $77 \%$ of academics and $58 \%$ of practitioners, respectively expect an increase. Academics (94\%) also expect an increase in FFA as against practitioners $(87 \%)$. 
Table 4. Demand for and Interest in FFA: Comparison of Academics Vs Practitioners

\begin{tabular}{lcccccc}
\hline & \multicolumn{2}{c}{ Litigation Support } & \multicolumn{2}{c}{ Expert Witnessing } & \multicolumn{2}{c}{ Fraud Examination } \\
\hline & Academics & Practitioners & Academics & Practitioners & Academics & Practitioners \\
\cline { 2 - 6 } Increase? & $83.8 \%$ & $75.0 \%$ & $77.2 \%$ & $57.8 \%$ & $94.3 \%$ & $86.9 \%$ \\
The same? & $2.7 \%$ & $8.9 \%$ & $11.4 \%$ & $35.8 \%$ & $5.7 \%$ & $4.3 \%$ \\
Decrease? & $13.5 \%$ & $13.5 \%$ & $11.4 \%$ & $6.4 \%$ & $0.00 \%$ & $8.7 \%$ \\
Total & $100 \%$ & $97.4 \%$ & $100 \%$ & $100 \%$ & $100 \%$ & $99.9 \%$ \\
\hline
\end{tabular}

Respondents were asked to indicate their level of agreement with perceptual anchors on the importance of each of the 9 items in the survey instrument in terms of the perceived benefits of each item to FFA education and practice. The survey instrument was anchored on a five-point Likert scale (varying from 'very important' $=5$ to 'unimportant' or 'not important' $=1$, with room for equivocation in the middle - the anchor 'moderately important' $=3$ ). Table 5 shows the respondents' perceptual rankings of the importance of perceived benefits of FFA education and practice. Academics consider 8 of the 9 items to be important, with mean responses higher than 3.75. The only item which is perceived as less important is strengthening the credibility of financial reporting, with a mean of 3.47. This contrasts with Rezaee et al.'s (2004) survey where the U.S. participating academics ranked this item as the most important. This disparity might be due to the timing difference in the two countries' surveys. The present Nigerian survey is ex post Nigeria's adoption of IFRS.

Thus, unlike the U.S. survey which was undertaken when there was still global concern about strengthening the credibility of financial reporting, such a concern had been cured or taken care of in Nigeria with the country's adoption of IFRS in January 2012. In effect, the U.S. study was ex ante IFRS adoption. On their part, participating practitioners consider 6 of the 9 items as important, with mean scores of 3.50 or higher. These mean scores, though relatively lower than the academics', not only correspond to a priori expectations of practitioners, but also corroborate the findings of Rezaee et al. Expectedly, practitioners place greater emphasis on education that prepares students for practice. They find preparing students to engage in expert witnessing, making students more desirable in the marketplace, preparing students to engage in fraud examination and preparing students to engage in litigation support consulting, in that order, as the most important benefits of FFA education.

Table 5. Perceived benefits of FFA education: academics vs practitioners (Academics $=37$, Practitioners $=111$ )

\begin{tabular}{|c|c|c|c|c|}
\hline Importance of perceived benefits of FFA education $\&$ practice & $\begin{array}{l}\text { Academics } \\
\text { Mean/(rank) }\end{array}$ & $\begin{array}{l}\text { Practitioners } \\
\text { Mean/(rank) }\end{array}$ & $\begin{array}{l}\text { Overall } \\
\text { Mean }\end{array}$ & $\begin{array}{l}\text { Mean } \\
\text { Rank }\end{array}$ \\
\hline $\begin{array}{l}\text { Satisfy society's demand for forensic accounting education and } \\
\text { practice. }\end{array}$ & $4.64(1)$ & $3.39(8)$ & 3.70 & 2 \\
\hline Strengthen the credibility of financial reporting. & $3.47(9)$ & $3.23(9)$ & 3.29 & 9 \\
\hline Promote responsible corporate governance. & $3.99(4)$ & $3.50(6)$ & 3.62 & 7 \\
\hline Make students more desirable in the market place. & $3.76(8)$ & $3.64(2)$ & 3.67 & 5 \\
\hline $\begin{array}{l}\text { Demand for individuals possessing forensic accounting education } \\
\text { and skills is increasing. }\end{array}$ & $3.85(5)$ & $3.62(4)$ & 3.68 & 3 \\
\hline Prepare students to engage in fraud examination. & $3.80(7)$ & $3.63(3)$ & 3.67 & 5 \\
\hline Prepare students to engage in litigation support consulting. & $3.85(5)$ & $3.62(4)$ & 3.68 & 3 \\
\hline Prepare students to engage in expert witnessing. & $4.45(2)$ & $4.45(1)$ & 4.45 & 1 \\
\hline Reduce the level of corporate fraud in the economy. & $4.17(3)$ & $3.44(7)$ & 3.62 & 7 \\
\hline
\end{tabular}

\subsubsection{Curriculum Development of FFA}

Respondents were asked to identify the most appropriate way to integrate FFA education (in terms of method, time and academic level) into the accounting curriculum in Nigeria's tertiary institutions. The results are presented in Table 6 in four panels. Panel A presents the results of the respondents' views on FFA integration. Over half $(52 \%)$ of the respondents reported that FFA should be offered as a separate course, while $41 \%$ preferred integration through extant financial accounting and audit courses. 
On the plan to introduce FFA into the curriculum, the question was restricted to academics as they have more direct involvement relations in curriculum development at the tertiary level than practitioners (Panel B). Nearly $65 \%$ indicated affirmative plans to introduce the course within one to two years. Another $24 \%$ said they would do so within five years, while $11 \%$ had no plans to introduce the course. A further analysis was undertaken to determine the level at which FFA should be introduced into the accounting programme. Panel $\mathrm{C}$ presents the results. Majority of the respondents (61\%) prefer FFA to be offered at both the graduate and undergraduate levels. A little over $16 \%$ prefer it at the graduate level while $23 \%$ want it at the undergraduate level. Their responses showed a symmetrical pattern, with $57 \%$ of academics and $51 \%$ of practitioners preferring it as a separate course. Panel D disaggregates Panel C into academic- and practitioner-respondent groups. Most academics (71\%) favour it at both the graduate and undergraduate levels against $58 \%$ by practitioners. In addition, $24 \%$ of academics and $14 \%$ of practitioners prefer it at the graduate level. Interestingly, only $6 \%$ of academics as against $29 \%$ of practitioners want the programme at the undergraduate level. This education preference supports the notion that practitioners place greater emphasis on the importance of preparing students for immediate engagement in practice.

Table 6. Curriculum development of fraud and forensic accounting (FFA)

Panel A: How should FFA education be integrated into academic curriculum? All Respondents $(\mathrm{n}=148)$

\begin{tabular}{lrr}
\hline & Frequency & Percent \\
\hline Integrate through accounting and auditing courses. & 61 & 41.2 \\
Offer fraud and forensic accounting as a separate course. & 77 & 52.0 \\
Do not cover fraud and forensic accounting at all. & 10 & 148 \\
Total & 6.8 & 100.0 \\
\hline
\end{tabular}

Panel B: If you do not currently offer any FFA course, when do you plan to do so? Academics $(\mathrm{n}=37)$

\begin{tabular}{lcc}
\hline & Frequency & Percent \\
\hline Within 1 year & 9 & 24.3 \\
Within 2 years & 15 & 40.6 \\
Within 5 years & 9 & 24.3 \\
Have no plan & 4 & 10.8 \\
Total & 37 & 100.0 \\
\hline
\end{tabular}

Panel C: At what level do you think FFA course should be offered? All Respondents $(n=148)$

\begin{tabular}{|c|c|c|}
\hline & Frequency & Percent \\
\hline Graduate & 24 & 16.2 \\
\hline Undergraduate & 34 & 23.0 \\
\hline Both Graduate and Undergraduate & 90 & 60.8 \\
\hline Total & 148 & 100 \\
\hline
\end{tabular}

Panel D: At what level do you think FFA course should be offered? Academics vs Practitioners

\begin{tabular}{|c|c|c|c|c|}
\hline & \multicolumn{2}{|c|}{ Academics } & \multicolumn{2}{|c|}{ Practitioners } \\
\hline & Frequency & Percent & Frequency & Percent \\
\hline Graduate & 9 & 24.3 & 15 & 13.5 \\
\hline Undergraduate & 2 & 5.4 & 32 & 28.8 \\
\hline Both Graduate and Undergraduate & 26 & 70.3 & 64 & 57.7 \\
\hline Total & 37 & 100 & 111 & 100 \\
\hline
\end{tabular}

\subsubsection{Content and Curriculum Development}

Having established increased demand for FFA education and training, a crucial question is what should be the curriculum content? The 25 items are drawn, mutatis mutandis, from Rezaee et al.'s (2004) U.S. survey. Since the benefits of these items are often not singularly independent, respondents were requested to treat each item as independent of the others and to assign as many ' $5 \mathrm{~s}$ ', ' $4 \mathrm{~s}$ ', ' $3 \mathrm{~s}$ ', etc., as they felt were warranted by the items included in the survey instrument. Table 7 reports academics' top five topics in order of importance as: (1) theory 
and methodology of fraud examination; (2) fundamentals of fraud; (3) Careers in forensic accounting; (4) anti-fraud auditing standards; and (5) Financial reporting standards and principles. Practitioners, on the other hand, ranked the following topics as most important: (1) Elements of fraud (pressure, opportunity and rationalization); (2) Occupational fraud; (3) Financial statement fraud; (4) Professional standards pertaining to forensic accounting; and (5) Anti-fraud auditing standards. It is clear that practitioners' topical interests are informed/influenced by their preference for practical topics that enhance students' immediate deployment in practice.

Table 7. Curriculum content of FFA education: comparison of academics vs practitioners

\begin{tabular}{llcc}
\hline & & Academics $\%$ & Practitioners $\%$ \\
\hline 1. & Theory and methodology of fraud examination & $75.7(1)$ & $43.2(9)$ \\
2. & Fundamentals of fraud & $75.7(1)$ & $41.4(11)$ \\
3. & Careers in forensic accounting & $73.0(3)$ & $25.7(23)$ \\
4. & Anti-fraud auditing standards & $67.6(4)$ & $46.8(5)$ \\
5. & Financial reporting standards and principles & $64.9(5)$ & $44.5(7)$ \\
6. & Shareholder litigation & $56.8(6)$ & $33.3(20)$ \\
7. & Criminology, white-collar and economic crimes & $54.9(7)$ & $40.9(13)$ \\
8. & Litigation consulting techniques & $51.4(8)$ & $43.1(10)$ \\
9. & Types of fraud (e.g., employees, management) & $48.6(9)$ & $44.5(7)$ \\
10. & Expert testimony and expert witness techniques & $48.6(9)$ & $35.1(17)$ \\
11. & Crime control techniques & $48.6(9)$ & $29.7(22)$ \\
12. & Financial Statement fraud & $47.2(12)$ & $48.6(3)$ \\
13. & Fraud detection and deterrence programs & $45.9(13)$ & $32.1(21)$ \\
14. & Elements of fraud: pressure, opportunity and rationalization & $45.9(13)$ & $50.5(1)$ \\
15. & Cyber and computer fraud & $45.9(13)$ & $34.2(19)$ \\
16. & Corporate governance & $43.2(16)$ & $25.2(24)$ \\
17. & Effective report writing & $41.7(17)$ & $36.0(16)$ \\
18. & Professional standards pertaining to forensic accounting & $37.8(18)$ & $47.3(4)$ \\
19. & Principles of ethics and corporate code of conduct & $37.8(18)$ & $24.3(25)$ \\
20. & Manipulation of related party transactions & $37.8(18)$ & $36.9(15)$ \\
21. & Legal elements of fraud & $37.8(18)$ & $35.1(17)$ \\
22. & Knowledge of the legal system & $37.8(18)$ & $41.4(11)$ \\
23. & Occupational fraud & $35.1(23)$ & $49.1(2)$ \\
24. & Intellectual property fraud & $35.1(23)$ & $46.4(6)$ \\
25. & Anti-fraud criteria, education, controls and training & $35.1(23)$ & $40.9(13)$ \\
\hline
\end{tabular}

\subsubsection{Obstacles to Integration}

Despite the overwhelming interest in integrating FFA into the accounting programme, perceived obstacles persist. Participating academics were asked to indicate the severity of a number of obstacles in integrating FFA education into the accounting curriculum. Table 8 shows the percentage of severity of the obstacles as well as the ranking differences between Nigerian and American academics (Rezaee et al., 2004). The main obstacles identified by academics are: lack of instructional materials, lack of faculty interest, lack of student interest, and lack of financial resources. Lack of administrative interest and support and lack of job opportunities were generally perceived as not severe.

Table 8. Perceived Obstacles to the Integration of FFA Education by Academics

\begin{tabular}{lccc}
\hline & Frequency (\%) & Rank & USA Rank \\
\hline Lack of instructional material & 67.6 & 1 & 2 \\
Lack of faculty interest & 45.9 & 2 & 4 \\
Lack of student interest & 32.4 & 3 & 6 \\
Lack of financial resources & 29.7 & 4 & 1 \\
Lack of administrative interest and support & 21.6 & 5 & 3 \\
Lack of job opportunities & 21.6 & 6 & 5 \\
\hline
\end{tabular}


The perceived severity of obstacles by Nigeria's academics are somewhat different from their American counterparts. For example, lack of instructional materials is seen by both Nigerian and American academics as a primary impediment to FFA integration (1 versus 2 ) and lack of job opportunities as less obstacle (6 versus 5). In the main, the results suggest that the major impediment to FFA education in Nigeria are institutional in nature (faculty, instructional materials and student interest), and not because of perceived lack of demand by employers, administrative support and funding. These findings partly corroborate the U.S. results and partly contradict them.

\subsection{Test of Hypotheses}

As already stated, the hypotheses were formulated to check the robustness of the consensus level of the respondent groups. The results of Kruskal-Wallis (K-W) and Chi-Square tests conducted in three key areas - (i) demand for, (ii) benefits of, and (iii) method of, FFA integration - are presented, seriatim. The study seeks to evaluate if there are significant differences between the perceptions of academics and practitioners on the demand for, and interest in, FFA education in Nigeria. The result, reported in Table 9, shows the mean ranks and $\mathrm{K}-\mathrm{W}$ test statistics.

Table 9. Future Demand and Interest in FFA Education

\begin{tabular}{llcccc}
\hline & Group & No. & Mean Rank & K-W & Sig. \\
\hline Litigation support & Academics & 37 & 59.93 & & \\
& Practitioners & 96 & 69.72 & & \\
\cline { 2 - 5 } Expert witnessing & Total & 133 & & 2.887 & .089 \\
\cline { 2 - 5 } & Academics & 27 & 62.18 & & \\
& Practitioners & 104 & 74.14 & & .084 \\
\cline { 2 - 5 } Fraud examination & Total & 141 & & 2.990 & \\
& Academics & 37 & 64.35 & & .143 \\
& Practitioners & 102 & 72.05 & & \\
\cline { 2 - 5 } & Total & 139 & & & \\
& & & & & \\
\end{tabular}

The K-W values lead to the acceptance of the null hypothesis of no significant differences between the academics and practitioners on the demand for and interest in FFA education in Nigeria.

Table 10. Perceived Benefits of FFA: K-W Test of Academics Vs Practitioners

\begin{tabular}{|c|c|c|c|c|c|c|}
\hline & & Respondents & No. & Mean Rank & K-W & Sig. \\
\hline \multirow[t]{3}{*}{ (A) } & Satisfy society's demand for forensic accounting & Academics & 37 & 92.81 & & \\
\hline & education and practice. & Practitioners & 110 & 67.67 & & \\
\hline & & Total & 147 & & 10.761 & .001 \\
\hline \multirow[t]{3}{*}{ (B) } & Strengthen the credibility of financial reporting. & Academics & 37 & 101.89 & & \\
\hline & & Practitioners & 110 & 64.62 & & \\
\hline & & Total & 147 & & 24.453 & .000 \\
\hline \multirow[t]{3}{*}{ (C) } & Promote responsible corporate governance. & Academics & 36 & 79.89 & & \\
\hline & & Practitioners & 108 & 70.04 & & \\
\hline & & Total & 144 & & 1.668 & .196 \\
\hline \multirow[t]{3}{*}{ (D) } & Make students more desirable in the market place. & Academics & 37 & 75.26 & & \\
\hline & & Practitioners & 109 & 72.90 & & \\
\hline & & Total & 146 & & 0.092 & .762 \\
\hline \multirow[t]{3}{*}{ (E) } & Increasing demand for individuals possessing FFA & Academics & 37 & 76.99 & & \\
\hline & education \& skills & Practitioners & 109 & 72.32 & & \\
\hline & & Total & 146 & & 0.379 & .538 \\
\hline \multirow[t]{3}{*}{ (F) } & Prepare students to engage in fraud examination. & Academics & 37 & 76.05 & & \\
\hline & & Practitioners & 109 & 72.63 & & \\
\hline & & Total & 146 & & 0.192 & .662 \\
\hline \multirow[t]{3}{*}{ (G) } & Prepare students to engage in litigation support & Academics & 37 & 77.03 & & \\
\hline & consulting. & Practitioners & 109 & 72.30 & & \\
\hline & & Total & 146 & & 0.380 & .538 \\
\hline
\end{tabular}




\begin{tabular}{|c|c|c|c|c|c|c|}
\hline \multirow[t]{3}{*}{$(\mathrm{H})$} & \multirow[t]{3}{*}{ Prepare students to engage in expert witnessing. } & Academics & 37 & 89.00 & \multirow{5}{*}{6.756} & \multirow{5}{*}{.009} \\
\hline & & Practitioners & 110 & 68.95 & & \\
\hline & & Total & 147 & & & \\
\hline \multirow[t]{3}{*}{ (I) } & \multirow{3}{*}{$\begin{array}{l}\text { Reduce the level of corporate fraud in the } \\
\text { economy. }\end{array}$} & Academics & 37 & 83.34 & & \\
\hline & & Practitioners & 107 & 68.75 & & \\
\hline & & Total & 144 & & 4.574 & .032 \\
\hline
\end{tabular}

As regards the perceived benefits of FFA education, Table 10 shows that there are differences of opinions between academics and practitioners with respect to benefits of FFA education. How significant are the differences? The results of the K-W test indicate that the differences are significant with respect to: (i) satisfying society's demand for forensic accounting education and practice, (ii) strengthening the credibility of financial reporting, (iii) preparing students to engage in expert witnessing, and (iv) reducing the level of corporate fraud in the economy. Thus, the null hypothesis is rejected for items A, B, H, and I. On the other hand, the null hypothesis of no significant differences in the perceptions of academics and practitioners with respect to the benefits of FFA education in Nigeria is accepted in respect of items C, D, E, F and G, that is: promoting responsible corporate governance, making students more desirable in the market place, increasing demand for individuals possessing FFA education and skills, preparing students to engage in fraud examination, and preparing students to engage in litigation support consulting.

The third hypothesis seeks to unravel significant differences, if any, between the perceptions of academics and practitioners on the mode of integrating FFA education into the accounting curriculum. The K-W Chi-Square test (Table 11) leads to a rejection of the null hypothesis, implying. that there are significant differences between academics' and practitioners' perceptions on the mode of integration.

Table 11. Methods of Integrating FFA Education into the Accounting Curriculum

\begin{tabular}{|c|c|c|c|c|c|}
\hline & Group & No. & Mean Rank & $\mathrm{K}-\mathrm{W}$ & Sig. \\
\hline \multirow{3}{*}{$\begin{array}{l}\text { What is the best way to integrate forensic accounting education } \\
\text { into the accounting curriculum? }\end{array}$} & Academics & 37 & 102.77 & & \\
\hline & Practitioners & 111 & 65.08 & & \\
\hline & Total & 148 & & 24.316 & .000 \\
\hline
\end{tabular}

\subsection{General Comments}

First, a review of related prior studies reveals increased future demand for and interest in forensic accounting, thus corroborating the studies of Rezaee \& Burton (1997); Carnes \& Gierlansinki (2001); and Rezaee et al. (2004). The findings of this study support policy initiatives that seek to promote FFA education to cope with the expected increase in future demand for FFA. Second, the null hypothesis of no significant differences in respondents' views regarding FFA benefits to an economy is accepted in most of the cases. This consensus result accords with Rezaee et al.'s (2004) study. It also supports Okunbor \& Obaretin's (2010) conclusion that forensic accounting could be effectively used to curb fraudulent activities in Nigeria. The unanimous position further buttresses the urgent need to put in place policy measures that would enhance integration of FFA education into accounting curriculum in Nigeria. Third, the study's findings concur with integrating FFA education at both the graduate and undergraduate levels. Respondents agree that this will enhance knowledge and skills but also will cohere with recent developments in the field, beyond what the undergraduate level will afford. In terms of pedagogy, respondents are of the view that cases, textbooks and research projects are the most important FFA learning tools.

Lastly, the study found lack of administrative interest and support less severe because with funding issues resolved, majority of academics would be able to obtain necessary administrative backing to offer FFA programmes. Also, lack of job opportunities was not considered severe because the demand for individuals possessing FFA skills is increasing, with more labour market openings in the future. Instead, the study finds that FFA integration is vulnerable to lack of instructional materials, faculty interest, student interest and financial resources. Low faculty and student interests are attributable to a number of policy-related factors, chiefly: lack of conducive infrastructure (policy, funding, and facilities), and learning and teaching environment to support new and existing programmes. There is a general funding apathy in Nigeria's educational system which restricts academic development. All these contrast with the situation in developed countries, where infrastructure and conducive teaching and learning environment are taken for granted. In Nigeria, academic staff lack necessary 
incentives to initiate new courses; parents and guardians are not motivated to enrol their wards into what they consider 'less glamorous programmes', especially in the face of high graduate unemployment. A very important policy impediment to FFA education is the inattention or reluctance of NUC, in particular, to establish BMAS for FFA programme. In general, educational development suffers from policy inertia and inconsistencies, funding gaps, administrative incompetence due to severe bounded rationality in policy making and programme implementation. All of these conspire to enervate educational development, including the introduction of new programmes, in Nigeria.

\section{Conclusions and Recommendations}

The purpose of this study was to explore the views of Nigerian academics and practitioners on the importance, relevance and delivery of FFA education, using a research instrument adapted from a similar U.S. survey. Evaluation was made using responses to a mail survey of 37 academics and 111 practitioners. The study has contributed to the literature in three ways: (1) it offers a (Nigeria vs U.S.) comparison of how academics and practitioners perceive the importance, relevance and delivery of FFA education in the two countries; (2) it suggests that bounded rationality in our university policy and regulatory framework, especially in NUC's limited capacity to develop BMAS in FFA education and in many academic programmes, contrary to self-development of university programmes in advanced economies, is a major impediment to effective academic development in Nigeria; and (3) it finds that there are significant differences between academics and practitioners on the mode of integrating FFA education into the accounting programme. A major conclusion from this study is that the future market for holders of FFA qualification is very bright and its relevance to national and global socioeconomic development is undeniable. The affirmative contents of FFA education and training include: (i) widening the employment horizon and opportunities of graduates; (ii) helping to combat corruption, fraud and financial crimes, (iii) strengthening the credibility of financial reporting, and (iv) helping to rebuild investors' confidence and trust in financial reports.

The empirical evidence of this study supports the theoretical conclusions reached by Herbert et al. (2017) in their review of the rise of FFA in Africa, wherein they contend that:

"FFA education cannot be conveniently subsumed under traditional accounting programmes. The leading difficulty where skills are idiosyncratic is that FFA education and training strategically require the incorporation of principles from a broad range of disciplines... The skill set and training is nearly impossible to capture under an accounting programme, thus making the current status of FFA in Nigeria and Africa in general ineffectual. Second, the design and implementation of the development agenda can be facilitated by the joint involvement of tertiary education regulatory agencies and FFA professionals... It will also enhance the supply of urgently needed skilled manpower in the fight against corruption and economic and financial crimes. Third, although Nigerian affiliates of foreign professional bodies, such as Association of Certified Fraud Examiners (ACFE, USA) and Institute of Certified Forensic Accountants (ICFA, Canada and USA), have sprung up, the extent to which they are meaningfully engaged in anti-fraud investigations and litigation support cases is minimal."

The present study's conclusions lend to the following recommendations. First, an urgent review of the role of BMAS in autonomous development of academic programmes in the Nigerian University System is expedient. Presently, no undergraduate or postgraduate programme can be undertaken in Nigeria without NUC accreditation in line with the BMAS as a necessary prolegomenon. Second, periodic fraud and forensic audit of public institutions and strategically important private companies should form part of a new and improved corporate governance code. This could be a corrective measure to stem both the culture and tide of systemic corruption in Nigeria. Third, mandatory requirement to attach FFA report in the prosecution of corruption, fraud and financial crimes, similar to the coroner's report in homicide prosecution, is desirable. Most corruption, fraud and financial crimes leave financial trails which, for the most part, may not easily be discerned or unravelled absent idiosyncratic accounting knowledge base and skills. There is a presumption that the prosecutorial failure or delay of many EFCC and ICPC cases is attributable to inchoate, hasty or want of diligent prosecution by law enforcement agents who eagerly publicize corruption allegations in the media even before commencing diligent investigations (Herbert et al., 2017). According to the authors, the leading reasons for want of diligent investigation and prosecution are rooted in corruption and opportunistic proclivities of government officials, judges and lawyers, on the one hand and the deliberate exclusion of experts, like fraud examiners and forensic accountants on the other, in investigations and prosecutions. In supporting the authors' position, the present study recommends the expediency of recruiting FFA specialists in fraud investigation and prosecution as expert witnesses. These measures would significantly animate the prosecution trajectory of these cases, a situation that is sadly lacking currently. The policy implications of systematic FFA education and training will work to (a) 
entrench the culture of transparency and accountability, (b) strengthen the fight against corruption, fraud and financial crimes, and (c) attenuate their systemic debilitating power or effect.

Finally, this study has its own limitations. Apart from the inherent limitations of being a replication study as already pointed out, it suffers from geographic limitation of survey respondents. A larger population and/or sample size drawn from wider geographical and institutional contexts will both be a corrective measure and provide a more robust analytical survey. These limitations notwithstanding, the implications of an empirical survey of this nature are not necessarily tainted nor are the reliability, validity and analysis of the data collected compromised.

\section{References}

Alexander, D., Burns, G., Manor, R., McRoberts, F., \& Torriero, E. A. (2002). The Fall of Andersen. Chicago Tribune, September 1.

Armstrong, J., \& Overton, T. (1977). Estimating Non-Response Bias in Mail Surveys. Journal of Marketing Research, 14, 396-402.

Bhasin, M. L. (2013). Corporate Governance and Forensic Accountants' Role: Global Regulatory Action Scenario. International Journal of Accounting Research, 1(1), 1-19.

Carnes, K. C., \& Gierlasinski, N. J. (2001). Forensic Accounting Skills: Will Supply Finally Catch Up to Demand? Managerial Auditing Journal, 16(6), 378-382.

Charan, R. (2005). Boards that Deliver: Advancing Corporate Governance from Compliance to Competitive Advantage. San Francisco: John Wiley \& Sons, Inc.

Crumbley, D. L. (2001). Forensic Accounting: Older Than You Think. Journal of Forensic Accounting, 2(2), 181-202.

Crumbley. D. L., \& Apostolou, N. (2002). Forensic Accounting: A New Growth Area in Accounting. Ohio CPA Journal, July - September.

Efiong, E. J. (2012). Forensic Accounting Education: An Exploration of Level of Awareness in Developing Economies - Nigeria as a Case Study. International Journal of Business and Management, 7(4), 26-34.

Herbert, W. E., \& Tsegba, I. N. (2013). Economic Consequences of International Financial Reporting Standards (IFRS): Evidence from a Developing Country. Research Journal of Finance and Accounting, 4(6), 121-135.

Herbert, W. E., \& Wallace, R.S.O. (1996). A Corporate View of Research Needs in Corporate Finance. Accounting and Business Research, 26(2), 107-124.

Herbert, W. E., Ene, E., \& Tsegba, I. N. (2014). Globalization of Financial Reporting: Obstacles to International Financial Reporting Standards (IFRS) Adoption in Nigeria. Asian Journal of Business and Management Sciences, 3(12): 25-41.

Herbert, W. E., Ene, E., Tsegba, I. N., \& Onyilo, F. (2017). The Rise of Fraud Examination and Forensic Accounting in Africa: The Nigerian Experience. Archives of Business Research, 5(4), 1-18. http://dx.doi.org/10.14738/abr.54.3013

KPMG. (2003). Fraud Survey. Montvale: New Jersey.

National Universities Commission. (2007). Benchmark Minimum Academic Standards for Undergraduate Programmes in Nigerian Universities. Abuja: NUC.

Okunbor, J. A., \& Obaretin, O. (2010). Effectiveness of the application of Forensic Accounting Services in Nigerian Corporate Organizations. Ambrose Ali University Journal of Management Sciences, 1(1), 171-184.

Oppenheim, A. N. (1966). Questionnaire Design and Attitude Measurement. London: Heinemann.

Peterson, B. K., \& Reider, B. (2001). An Examination of Forensic Accounting Courses: Content and Learning Activities. Journal of Forensic Accounting, 2(1), 25-41.

Peterson, B. K., \& Reider, B. P. (1999). Fraud Education of Accounting Students: A Survey of Accounting Educators. The National Accounting Journal, 23-30.

PricewaterhouseCoopers. (2003). Global Economic Crime Survey. New York: PWC.

Ramadhan, S. (2015). Certified Accountants' Perception of Forensic Accounting Education: The Case of Bahrain. International Journal of Finance and Accounting, 4(2), 109-118.

Rezaee, Z., \& Burton, E. J. (1997). Forensic Accounting Education: Insights from Academicians and Certified 
Fraud Examiner Practitioners. Managerial Auditing Journal, 12(9): 479 - 489.

Rezaee, Z., Crumbley, D. L., \& Elmore, R. C. (2004). Forensic Accounting Education: A Survey of Academicians and Practitioners. Advances in Accounting Education, Teaching and Curriculum Development, 6(2), 193-231.

Rezaee, Z., Reinstein, A., \& Lander, G. H. (1996). Integrating Forensic Accounting into the Accounting Curriculum. Accounting Education, 1(2), 147-162.

Simon, H. A. (1972). Theories of Bounded Rationality. In McGuire, C. \& Radner, R. (Eds.), Decision and Organization. Amsterdam: North-Holland Publishing Co. (pp. 161-176).

Simon, H. A. (1982). Models of Bounded Rationality. Cambridge, MA: MIT Press.

Wallace, R. S. O., \& Mellor, C. J. (1988). Nonresponse Bias in Mail Accounting Surveys: A Pedagogical Note. The British Accounting Review, 20: 131-139.

Williamson, O. E. (1975). Markets and Hierarchies: Analysis and Antitrust Implications. New York: The Free Press.

Zachariah, P., Masoyi, A. D., Ernest, E. I., \& Gabriel, A. O. (2014). Application of Forensic Auditing in Reducing Fraud Cases in Nigeria Money Deposit Banks. Global Journal of Management and Business Research, 14(3), 14-22.

Zango, A. G. (2012). The Relevance of Forensic Accounting Education in Financial Reporting. Umaru Musa Yar'adu University Faculty of Management and Social Sciences Working Paper Series.

\section{Notes}

Note 1. The eight (8) banks are Union Bank of Nigeria Plc, Afribank Nigeria Plc, Intercontinental Bank Plc, Wema Bank Plc, Oceanic Bank International Plc, Bank PHB Plc, Finbank PLc, and Spring Bank Plc. Apart from corporate governance deficits, the Central Bank of Nigeria (CBN) adjudged these banks to have had significant deficiencies in liquidity and risk management policies, both of which are derivative conditions of governance failure and accounting manipulations. Consequently, the board and management of the 8 banks were sacked as part of the CBN's bailout with the injection of N620 billion ( $\$ 3.9$ million) Tier 2 capital.

Note 2. The term ' 419 ' is a euphemism for the offence of, and punishment for, advance fee fraud, obtaining under false pretence, punishable under Section 419 of Nigeria's Criminal Code Act. In effect, '419' is a law in Nigeria, derived from Section 419 of the Nigerian Criminal Code Act Part VI Chapter 38. The section deals with obtaining under false pretences or cheating.

Note 3. A rule of thumb for purposive sample, also known as judgmental sample, is that the selection is based on the knowledge of the population (such as, characteristics) and the purpose of the study. Because FFA is distinctive and warrants idiosyncratic knowledge and skills, eliciting responses through surveys is akin to studying extreme or deviant phenomena, cases that do not fit into regular patterns of sampling, as in conventional accounting topics or practice.

Note 4. Multistage sampling technique, essentially takes random samples of preceding random samples. Though not as effective as true random sampling, however, it solves more of the problems inherent in random sampling. It is effective and useful as a strategy because it banks on multiple randomizations. This technique is used frequently when a complete list of all members of the population does not exist or is found inappropriate for the study. Moreover, by avoiding the use of all sample units in all selected clusters, multistage sampling avoids the large, and perhaps unnecessary, costs associated with traditional cluster sampling.

Note 5. Idiosyncratic knowledge is one that requires significant job-specific skills and related task-specific knowledge (Williamson, 1975). They are usually higher-level jobs within the organization. Williamson (1975) posits that training for these jobs involves the acquisition of task-specific and firm-specific skills, occurs in an on-the-job context, and often involves a team element. These are the distinguishing characteristics of the fraud examiner and forensic accountant.

Note 6. Rationality is bounded when the decision-making process or the decision-maker is limited by reason of (a) outright ignorance or lack of knowledge, (b) cognitive capacity, (b) numeracy and storage capacity, (d) language and communication capacity, and (e) adverse selection due to asymmetric information. All human beings, and all human decision-makers for that matter are boundedly rational, that is, "intendedly rational, but only limitedly so" (Williamson, 1975; Simon, 1972, 1982). Because human beings are limited in knowledge, 
foresight, skill, and time, their ability to interpret, process or recall accurately a set of information and/or consummate a given set of transactions is bounded by neurophysiological as well as language limits (Williamson, 1975).

\section{Copyrights}

Copyright for this article is retained by the author(s), with first publication rights granted to the journal.

This is an open-access article distributed under the terms and conditions of the Creative Commons Attribution license (http://creativecommons.org/licenses/by/4.0/). 